\title{
AN EVALUATION ON LEVELS OF KNOWLEDGE, ATTITUDE AND BEHAVIOR OF PEOPLE AT 65 YEARS AND ABOVE ABOUT ALTERNATIVE MEDICINE LIVING IN ANKARA
}

\author{
Özlem Özer ${ }^{a^{*}}$; Fatih Şantaş ${ }^{a}$; Hasan Hüseyin Yıldırıma ${ }^{a}$

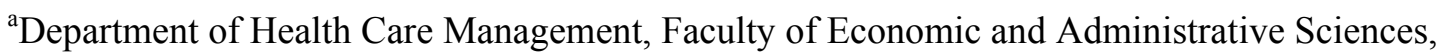 \\ Hacettepe University, Ankara, Turkey. \\ *E-mail: ozlem.ozer@hacettepe.edu.tr
}

\begin{abstract}
The aim was to determine the knowledge, attitude and behavioral levels of people at and above 65 years of age, living in Ankara (Turkey) about alternative medicine. The study was carried out between March - April 2010 through survey application of 200 participants by selective random sampling from the population. Data obtained as a result of the survey were analyzed by SPSS program. The study revealed that $83.5 \%$ of the participants believed in alternative therapy methods but $16.5 \%$ of them did not. It is concluded that herbal therapy methods are the most frequently used methods with a $63 \%$ rate among other alternative therapy methods. When status of the participants was analyzed it was found that it was found that $69 \%$ received the information about alternative medicines from their family while $53.5 \%$ received it from television This study revealed that alternative medicine is profoundly used by people above 65 years of age in Ankara.
\end{abstract}

Key Words: Alternative - Complementary Medicine, Herbal Therapy, 65 years and above, Turkey

\section{Introduction}

From the middle of the twentieth century, rapid developments have been observed in the diagnosis and therapy of diseases associated with the increase in the use of complementary and alternative therapies (Muslu and Öztürk, 2008). The applications of diagnosis, therapy and protection from diseases which contribute to general medicine methodology as complementary and do not take place as conception under the name of classical medicine are often referred to as complementary - alternative medicine (CAM). CAM consists of special medical methods using natural substances and specific solutions, different therapy and exercise techniques in order to ensure the individual is at peace with him/herself, family and social environment and to recognize him/herself in a better way towards protecting his/her physical and mental health (Dıraçoğlu, 2007).

The use of CAM varies according to patients' faith, religion, life-style and culture (mostly because certain vegetations growing in certain geographical areas are known better) (Tokem, 2006). Use of CAM is based on various reasons such as (i) aversion felt against medical therapy; (ii) mechanism to overcome the disease actively: (iii) to save oneself from remaining passive and demoralization, tension, and also (iv) to avoid losing control. Other reasons why the use of CAM seemed attractive may be stated as follows; cultural values shared inside and strengthening the patient, being authentic, giving the feeling that patient is connected and interacting with the world in the case of being ill (Çetin, 2007). It is possible to specify the main CAM methods as explained in the following; (1) Alternative medical systems: Homeopathy, naturopathic medicine, ayurveda. (2) Mental - Physical Methods: Meditation, prayer, mental healing, music, art, dance. (3) Biological based therapies: Herbals, foods, vitamins. (4) Manipulative body - based methods: massage, manipulation, chiropractics. (5) Energetic therapies: Bio-field therapies (reiki, therapeutic touch) and bio-electromagnetic based therapies (use of electromagnetic field) (Durmaz, 2011).

Complementary medicine applications are used as a type of therapy which is affordable and easy to get across to developing and underdeveloped countries and preferred by the overall population. In the WHO Malaria Reduction Program carried out in 1998; it is reported that $60 \%$ of children with high - fevers are cured at home with medications made of herbs in Ghana, Mali, Nigeria and Zambia (Özdemir, 2009). Today, $80 \%$ of the population in Asian and African countries and approximately $70 \%$ of the population in most developed countries are using at least one of these alternative therapy methods. In a study done in 1991, it is found that 1400 different types of herbal medicines are used in EU member states. Furthermore, a study done by the Pacoe firm in Germany, it was found that people trust in alternative medicine at an $80 \%$ rate and only $12 \%$ of them rely on Orthodox medicine (http://www.duyurucu.com/k43114-almanya-da-alternatif-tip.html).

MacLennan et. al. (1996), conducted a survey of about 3004 people at and above 15 years of age, living in southern Australia. $48.5 \%$ of the people used at least one of the alternative therapy methods. In the interviews conducted by Barnes et. al. (2004) using about 31,044 people at and above 18 years of age, living in America; $62 \%$ of them have used at least one of the alternative therapy methods throughout the last 12 months. The results of a survey applied by Foster et. al. (2000) with about 2,055 people, showed that in order to determine the status of people at and above 65 years of age using alternative medicine methods, $30 \%$ of the participants used at least one of the alternative therapy methods. Cohen et. al. (2002) determined the rate of using alternative and complementary medicine among 182 people at and above 65 years of age at a hospital in New York between 1998 and 1999 as 64\%. Hanssen et.al. (2005) investigated the use of complementary and alternative medicine in Scandinavian countries.To do this, 16690 face to face interviews have been done in Denmark while 1000 and 1001 interviews have been performed on the phone in Norway and Stocholm respectively. It is found that $34 \%$, 
$45 \%$ and $49 \%$ of randomly selected samples in Norway, Denmark and Stockholm respectively, use alternative and complementary medical methods Lim et. al. (2005) concluded that $76 \%$ of 393 people at and above 18 years of age in Singapore have used at least one CAM method within the last 12 months, and women appeared to use these methods $2.1 \%$ higher than men do. In the study performed by Huillet et. al. (2011) for the determination of complementary and alternative therapy methods used on children at military pediatric clinics, it is revealed that the most commonly used CAM method is herbal therapy. In the study performed by Onyiapat et. al. (2011) in Nigeria on 732 people whose ages ranged from 18 to 65, the rate of those using CAM is found to be $84.7 \%$. The most commonly used CAM product was biological products. See et. al. (2010) concluded that $25.7 \%$ of 855 hospitalized patients at dermatology clinic use CAM methods and patients often expect recommendations from dermatologists about CAM methods. In the study performed by Hall et. al. (2011) for the determination of CAM among pregnant women, it was found that many women use complementary and alternative medical methods in the course of their pregnancy. In the study performed by Neto et al. (2009), it was concluded that use of complementary and alternative medicine had a positive relationship with gender, territory, income, educational and marital status. In the study performed by Khalaf and Whitford (2010) concerning the use of CAM among patients with diabetes, it was found that in the two diabetes clinics in Bahrain, the use of CAM among patients with diabetes was profoundly high. In the study performed by Richmond et. al. (2010) regarding the use of CAM among patients with hepatitis C, it is found that patients mostly use prayer, multivitamin and herbal methods, respectively. Herrera - Arellano et. al. (2009) investigated the use of CAM among/across the patients with HIV and found that $73.4 \%$ of them use CAM. Moreover/Furthermore it is found that the most commonly used methods are multivitamins and herbal products.

Within the Turkish territory, there are few studies in the literature about complementary and alternative medicine. As a result of the study performed by Tan et. al. (2004) at two university hospitals within eastern Turkey in order to determine the tendency of using complementary and alternative therapy, it is concluded that $70 \%$ of participants use CAM and the most commonly used methods are herbal methods at $41 \%$. As a result of the survey applied by Araz et. al. (2007) in Izmir on 1000 people, whose ages ranging from 18 and 80, in order to reveal attitude of health and use of alternative therapy, it is concluded that half of them prefer only to consult a doctor for a cure in case of an illness. However, one - third of them seeks any other way of cure besides consulting a doctor. In addition, it is found that the most appealing CAM method is prayer. As a result of a survey applied by Çetin (2007) of 300 people living in Eskisehir downtown, regarding the examination of the levels and variety of using complementary and alternative therapy and the factors affecting CAM use in Eskisehir; it is concluded that $60 \%$ of the respondents use various CAM methods and there is no significant effect of sociodemographic characteristics on overall use of CAM. In his study named as use of complementary and alternative medicine on patients with asthma, Tokem (2006) ascertained that the most commonly used CAM methods preferred by parents of children with asthma are massage, relaxation techniques, regime and vitamins. For adults with asthma, its nutrition, regime supplementary products, herbal therapies, meditation and homeopathy.

\section{Methodology}

The aim of this study is to determine the knowledge, attitude and behavioral levels of the people at and above 65 years of age, living in Ankara about alternative medicine. In the study performed between March and April in 2010, a survey was applied to 200 randomly selected samples from the population. The Ankara metropolitan area, which is the population of the study, is composed of 16 towns. These towns create clusters. Due to research limitations such as costs, twoof those clusters were selected by a simple random sampling method. The questionnaire was administered to 200 randomly selected samples at and above 65 years of age, residing in those two districts among 2000 people. The questionnaire is made of three sections. In the first section, the socio-demographical characteristics of participants such as gender, age, marital status, educational status, occupational status, number of household and type of family have been asked. In the second section, some questions take place regarding participants' status of believing alternative therapy, reasons of preferring alternative therapy methods and in which diseases they use alternative and complementary therapy most frequently. In the third section, the data is obtained regarding the methods of therapies applied for various diseases and their recipes. The data obtained were analyzed bya statistical software (SPSS program version 11.5). The Constraints of the study are that; the samples with no education were not able to answer the questions. They hardly understood the questions due to old - age and some participants with prejudice to alternative medicine.

\section{Results and Discussion}

The demographical characteristics of 200 people who participated in the survey are shown in Table 1 . According to Table $1.30 .5 \%$ of participants are men and $69.5 \%$ of them are women; $68.5 \%$ of them are married, $2 \%$ of them are single, $6 \%$ of them are divorced and $23.5 \%$ of them are widowed. As for their educational status; $5.5 \%$ of them are illiterate, $12 \%$ of them are literate. $34.5 \%$ of them have graduated from primary school, $16 \%$ of them from secondary school or an equivalent, $17.5 \%$ of them from high school or equivalent and $14.5 \%$ of them from university.

The distribution according to employment status and household characteristics of participants are shown in Table $2.5 \%$ of the participants are employed, $95 \%$ of them are retired; $71.5 \%$ of them have a nuclear family, $22.5 \%$ of them have large family; $5 \%$ of them have patriarchal family, and $1 \%$ of them have a separated family. 


\section{http://dx.doi.org/10.4314/ajtcam.v10i1.18}

Table 1: Distribution of Participants According to Their Demographical Characteristics

\begin{tabular}{|c|c|c|}
\hline Variables & Number (n) & Percentage $(\%)$ \\
\hline \multicolumn{3}{|l|}{ Age } \\
\hline $65-70$ & 145 & 72.5 \\
\hline $76-80$ & 11 & 5.5 \\
\hline 81 and above & 2 & 1 \\
\hline Total & 200 & 100 \\
\hline Male & 61 & 30.5 \\
\hline Female & 139 & 69.5 \\
\hline Total & 200 & 100 \\
\hline \multicolumn{3}{|l|}{ Marital Status } \\
\hline Married & 137 & 68.5 \\
\hline Total & 200 & 100 \\
\hline \multicolumn{3}{|l|}{ Educational Status } \\
\hline Illiterate & 11 & 5.5 \\
\hline Literate & 24 & 12 \\
\hline Primary school & 69 & 34.5 \\
\hline Secondary school or equivalent & 32 & 16 \\
\hline High school or equivalent & 35 & 17.5 \\
\hline University & 29 & 14.5 \\
\hline Total & 200 & 100 \\
\hline
\end{tabular}

Table 2: Distribution of Participants According to Their Employment Status and Household Characteristics

\begin{tabular}{|c|c|c|}
\hline Employment Status & Number (n) & Percentage $(\%)$ \\
\hline Employed & 10 & 5 \\
\hline Retired & 190 & 95 \\
\hline Total & 200 & 100 \\
\hline \multicolumn{3}{|c|}{ Number of people living in the household } \\
\hline 1 & 15 & 7.53 \\
\hline 2 & 52 & 26.13 \\
\hline 4 & 46 & 23.11 \\
\hline 5 & 23 & 11.55 \\
\hline 6 & 14 & 7.0 \\
\hline 7 & 6 & 3.01 \\
\hline 8 & 6 & 3.01 \\
\hline Total & 200 & 100 \\
\hline \multicolumn{3}{|l|}{ Type of Family } \\
\hline Nuclear family & 143 & 71.5 \\
\hline Large family & 45 & 22.5 \\
\hline Patriarchal family & 10 & 5 \\
\hline Separated family & 2 & 1 \\
\hline Total & 200 & 100 \\
\hline
\end{tabular}

Attitudes and behaviors of those participated to the survey about alternative therapy methods are examined in Table 3. It is revealed that $83.5 \%$ of participants believe in alternative therapy methods, $16.5 \%$ of them do not so; $65 \%$ of them have appealed to alternative therapy methods in the past, $35 \%$ never have. It is revealed that participants mostly believe in herbal therapy with a $63 \%$ rate. The reason why alternative therapy methods are mostly preferred, is with $56.5 \%$ the status of conviction that it would be fructuous when combined with traditional therapy. It is determined that those who believe that alternative therapy methods are used consciously in our country are $14 \%$, those who do not believe are $43.5 \%$ and those who don't have any idea about that issue are $42.5 \%$. 


\section{http://dx.doi.org/10.4314/ajtcam.v10i1.18}

Table 3: Attitudes of Participants about Alternative Therapy Methods

\begin{tabular}{|c|c|c|}
\hline Status of conviction to alternative therapy methods & $\begin{array}{l}\text { Number } \\
(\mathrm{n})\end{array}$ & \begin{tabular}{|l} 
Percentage \\
$(\%)$
\end{tabular} \\
\hline Yes & 167 & 83.5 \\
\hline No & 33 & 16.5 \\
\hline Total & 200 & 100 \\
\hline \multicolumn{3}{|l|}{ Status of appealing to alternative therapy methods in the past } \\
\hline Yes & 130 & 65 \\
\hline No & 70 & 35 \\
\hline Total & 200 & 100 \\
\hline \multicolumn{3}{|l|}{ Status of conviction to alternative therapy methods } \\
\hline Acupuncture, Herbal & 1 & 0.5 \\
\hline Herbal Theory & 126 & 63 \\
\hline Bio - energy & 1 & 0.5 \\
\hline Massage & 1 & 0.5 \\
\hline No answer & 71 & 35.5 \\
\hline Total & 200 & 100 \\
\hline \multicolumn{3}{|l|}{ Status of preferring alternative therapy methods } \\
\hline Whereas it would be fructuous combined with traditional therapy & 113 & 56.5 \\
\hline Whereas it would be interesting to try these methods & 5 & 2.5 \\
\hline Whereas traditional medicine would not help my health problems & 15 & 7.5 \\
\hline Whereas I found traditional medicine expensive & 14 & 7 \\
\hline No answer & 53 & 26.5 \\
\hline Total & 200 & 100 \\
\hline \multicolumn{3}{|l|}{$\begin{array}{l}\text { Status of conviction that alternative therapy methods are being } \\
\text { used in our country consciously. }\end{array}$} \\
\hline Yes & 28 & 14 \\
\hline No & 87 & 43,5 \\
\hline No idea & 85 & 42,5 \\
\hline Total & 200 & 100 \\
\hline \multicolumn{3}{|l|}{ Status of conviction to what the alternative medicine is } \\
\hline Sports & 3 & 1.5 \\
\hline Herbal therapies & 112 & 56 \\
\hline Healthy life & 13 & 6.5 \\
\hline Supplementary cure & 56 & 28 \\
\hline Healthy diet & 9 & 4.5 \\
\hline Healing & 7 & 3.5 \\
\hline Total & 200 & 100 \\
\hline
\end{tabular}

Status of how participants access the information on alternative medicine is examined in Table 4 and it is revealed that $69 \%$ of the information is obtained from family and $53.5 \%$ from television.

Table 4: Status of Participants Access to the Information about Alternative Medicine

\begin{tabular}{|l|l|l|}
\hline Status of accessing the information about alternative medicine & Number (n) & Percentage (\%) \\
\hline Family & 138 & 69 \\
\hline Radio & 12 & 6 \\
\hline Newspaper - Magazine & 76 & 38 \\
\hline Internet & 14 & 7 \\
\hline Television & 107 & 53.5 \\
\hline Posters - billboards & 1 & 0.5 \\
\hline No idea & 12 & 6 \\
\hline Other & 38 & 19 \\
\hline Environment & 6 & 3 \\
\hline
\end{tabular}

The status of participants using alternative and modern medicine methods is examined in Table 5 and it is determined that those who believe that natural medicines are more effective than modern medicine is $11.5 \%$ and those who don't believe are $27 \%$. Those who believe they are effective in occasional situations is at $61.5 \%$. It is also revealed that in case an illness occurred which cannot be remedied by modern medicine, those who would use alternative therapy methods are $66.5 \%$; those who stated that they would not think of using alternative therapy methods even in such case are $7 \%$. 


\section{http://dx.doi.org/10.4314/ajtcam.v10i1.18}

Table 5: Distribution of Participants According to Use of Modern Medicine and Alternative Medicine

\begin{tabular}{|l|l|l|}
\hline State of natural medications being more effective than modern medicine & Number (n) & Percentage (\%) \\
\hline Yes & 23 & 11.5 \\
\hline No & 54 & 27 \\
\hline In some cases & 123 & 61.5 \\
\hline Total & $\mathbf{2 0 0}$ & $\mathbf{1 0 0}$ \\
\hline $\begin{array}{l}\text { State of modern medicine and alternative medicine being effective on } \\
\text { healing }\end{array}$ & \\
\hline Modern medicine & 74 & \\
\hline Alternative medicine & 20 & 37 \\
\hline Both & 106 & 10 \\
\hline Total & $\mathbf{2 0 0}$ & 53 \\
\hline $\begin{array}{l}\text { State of using alternative therapy methods in case of an illness which cannot } \\
\text { be remedied by modern medicine }\end{array}$ & $\mathbf{1 0 0}$ \\
\hline Yes & 133 \\
\hline No & 14 \\
\hline No Idea & 53 \\
\hline Total & $\mathbf{2 0 0}$ \\
\hline
\end{tabular}

State of participants using herbal drugs is examined in Table 6 and it is found that $26 \%$ of participants think that physicians' false attitudes mostly lead to the use of herbal drugs which is called alternative medicine gaining wide currency. It is revealed that those who deem prayer as an alternative medicine are $67 \%$, those who do not so are $33 \%$.

Table 6: Distribution of Participants According to Their Status of Using Herbal Drugs

\begin{tabular}{|l|l|l|}
\hline Reasons why use of herbal drugs gains wide currency & Number (n) & Percentage (\%) \\
\hline Drug prices & 49 & 24.5 \\
\hline False attitudes of physicians & 52 & 26 \\
\hline Ads of drug firms & 10 & 5 \\
\hline No idea & 85 & 42.5 \\
\hline No answer & 4 & 2 \\
\hline Total & $\mathbf{2 0 0}$ & $\mathbf{1 0 0}$ \\
\hline Reasons why people use herbal drugs & \\
\hline Due to lack of education & 31 & 15.5 \\
\hline Due to being remediless & 118 & 59 \\
\hline Due to having economic difficulties & 30 & 15 \\
\hline Due to lack of trust on modern medicine & 21 & 10.5 \\
\hline Total & $\mathbf{2 0 0}$ & $\mathbf{1 0 0}$ \\
\hline Status of considering pray as an alternative therapy method when get sick & & \\
\hline Yes & 134 & 67 \\
\hline No & 66 & 33 \\
\hline Total & $\mathbf{2 0 0}$ & $\mathbf{1 0 0}$ \\
\hline
\end{tabular}

On Table 7, the question asked to participants for which diseases they most frequently use alternative and complementary therapy methods and on the top with $43 \%$, it is found they use them for lumbar and back pains.

\section{Conclusion}

In recent years, the use of alternative therapy methods and the status of people believing in these methods has increased. Those who participated to the survey believe that alternative therapy methods would be more fructuous when combined with modern medicine and they might use alternative therapy methods when they catch an illness that modern medicine fails to remedy. Alternative therapy methods are mostly learnt from family and television. The therapy method in which the majority of participants believe in is herbal therapy. The reason why people use herbal therapy results mostly from believing that they are desperate. However, many people count prayer as an alternative therapy method when they get sick. It is observed that vegetation and/or methods used in diseases, though there are little differences according to the territory, are generally identical. Those who participated in the survey think that alternative medicine's methods they use are often 


\section{http://dx.doi.org/10.4314/ajtcam.v10i1.18}

effective. With this study, it is concluded that the use of alternative medicine among people at and above 65 years of age, living in Ankara is significantly high.

Table 7: Use of Alternative and Complementary Therapy Methods According to Diseases

\begin{tabular}{|l|l|l|}
\hline & Number (n) & Percentage (\%) \\
\hline Lumbar and back pains & 86 & 43 \\
\hline Rheumatism & 59 & 29.5 \\
\hline Influenza & 56 & 28 \\
\hline Depression & 11 & 5.5 \\
\hline Headache & 62 & 31 \\
\hline Insomnia & 47 & 23.5 \\
\hline Diarrhoea & 1 & 0.5 \\
\hline Cancer & 7 & 3.5 \\
\hline Stomach-ache & 1 & 0.5 \\
\hline Cholesterol & 1 & 0.5 \\
\hline Cough & 1 & 0.5 \\
\hline Prostate & 1 & 0.5 \\
\hline Total & 1 & $\mathbf{1 0 0}$ \\
\hline
\end{tabular}

Table 8 shows some alternative therapy methods used by participants for some diseases.

Table 8: Alternative Therapy Methods Used by Participants

\begin{tabular}{|c|c|}
\hline Inflammatory diseases & Applying vinegar - water cure, linden, stinger, rose hip, taking a warm bath. \\
\hline Sore throat & $\begin{array}{l}\text { Boiling apple and/or quince then bandaging them to neck, linden, garden sage, rose hip, } \\
\text { daisy tea, bay leaf, milk - starch, water - lemon, thymus oil, mint oil. }\end{array}$ \\
\hline Dyspnea & $\begin{array}{l}\text { Ginger, aniseed, mixture of flaxseed \& honey, thymus extract, blackberry, black } \\
\text { mulberry, quince leaf, daisy tea. }\end{array}$ \\
\hline Gingival bleeding & Mouthwash with carbonated or salty water \\
\hline Stomach gas & Aniseed tea, fennel tea, veronica, daisy tea \\
\hline Ulcer, stomach - ache & Warm milk with honey, Turkish delight, sorbet, sesame oil \\
\hline Dyspepsia & Mustard seed, mineral water, carbonated water, parsley, ginger, linden \\
\hline Headache & $\begin{array}{l}\text { Bandaging raw potato slices around the head by using a cheesecloth, placing peelings of } \\
\text { cucumber on the head, daisy tea, stinger tea }\end{array}$ \\
\hline Lumbar pain & $\begin{array}{l}\text { Bandaging trout, cupping, dressing, belting, bandaging warm blanket made of mat, } \\
\text { bandaging black pepper pounded with honey, bandaging resin. }\end{array}$ \\
\hline Back pain & Cupping, dressing, massage with olive oil or balsam. \\
\hline Ear pain & $\begin{array}{l}\text { Dropping warm breast milk or olive oil into the ear, bandaging ear with garlic or onion, } \\
\text { dropping almond oil or thymus oil, dropping apple juice or leek juice into ear. }\end{array}$ \\
\hline Diarrhoea & $\begin{array}{l}\text { Boiled potato, rice mush, mixture of coffee - lemonade, coke, banana, peach, starch, } \\
\text { wild pear, apple, yellow chickpeas. }\end{array}$ \\
\hline Constipation & $\begin{array}{l}\text { Apricot (dried, jam or compote), fig, plum, flaxseed, cassia, olive oil, honey with hot } \\
\text { water. }\end{array}$ \\
\hline Hypertension & Water - lemon, garlic, mistletoe, sugared water, thorn apple. \\
\hline Hypotension & $\begin{array}{l}\text { Buttermilk, lemon, salty buttermilk, chocolate, cube sugar, garlic, mistletoe, lemonade, } \\
\text { sugared water. }\end{array}$ \\
\hline Dizziness & Spleen, buttermilk, water - lemon, rosemary, mixture of mint and basil leaves. \\
\hline Itchiness & $\begin{array}{l}\text { Taking shower with salty water, green tea, eating powder sugar and sulphur, applying } \\
\text { wet soil }\end{array}$ \\
\hline Diabetes & $\begin{array}{l}\text { Bitter almond, sour apple, grapefruit, locust, thymus extract, rose hip, grenadine extract, } \\
\text { myrtle leaf, pomegranate syrup, cortex cinnamon, olive leaf, alchemilla, laurel seed, } \\
\text { blackberry jam, euonymus. }\end{array}$ \\
\hline Evil eye & $\begin{array}{l}\text { Prayer against evil eye, harmal seed, smoking flour, pouring molten lead into a cup over } \\
\text { one's head who is affected by evil eye, charm, evil eye bead, fumigation, putting garlic } \\
\text { or wild chestnut into pocket. }\end{array}$ \\
\hline Wound & $\begin{array}{l}\text { Applying honey and tail fat, pine resin, mixture of soap and butter, bandaging grated } \\
\text { apple, not pounded flesh, crumb, cooked onion, and garlic, sweet dough, applying }\end{array}$ \\
\hline
\end{tabular}




\begin{tabular}{|c|c|}
\hline & flaxseed oil, rubbing cigarette ash or tobacco into wound. \\
\hline Fraction & $\begin{array}{l}\text { Drinking sheep's head and foot soup, securing mixture of egg, soap and flour to the } \\
\text { fractured area with a splint, bandaging with pounded grape and olive, bandaging with } \\
\text { sweet dough or oily fabric, massage with suds. }\end{array}$ \\
\hline Inflammatory burns & $\begin{array}{l}\text { Ice or cold water cure, applying yogurt or paste, tomato paste, bandaging with mixture of } \\
\text { egg - white, olive oil, wax and starch. }\end{array}$ \\
\hline Dislocation & Applying honey, olive oil, flesh, massage with soap, bandaging with onion. \\
\hline Insomnia & $\begin{array}{l}\text { Garden sage, milk, yogurt, aniseed, buttermilk, herbal teas, warm milk, thymus tea, daisy } \\
\text { tea, fennel tea, poppy. }\end{array}$ \\
\hline Pregnancy & $\begin{array}{l}\text { Mandrake, parsley, milfoil, natural trout, date, rose hip, daisy tea, milk, yogurt, cheese, } \\
\text { ginger, cardamom, coconut milk, cinnamon, mesir paste. }\end{array}$ \\
\hline Puerperium & $\begin{array}{l}\text { Royal jelly, cracked wheat soup, sugar beet, linden, slabs of sugar flavoured with spices } \\
\text { and dyed red, compote, mistletoe, molasses, milky soap, scallion. }\end{array}$ \\
\hline Whooping cough & $\begin{array}{l}\text { Quince leaf, juniper root, milk with honey, honey, lemon, linden, thymus, rose hip, } \\
\text { clove, molasses, daisy extract, cinnamon, ginger root, olive leaf, veronica, onion extract. }\end{array}$ \\
\hline Measles & $\begin{array}{l}\text { Measles candy (as known in public, same as slabs of sugar flavoured with spices and } \\
\text { dyed red), molasses, bath with salty water. }\end{array}$ \\
\hline Aphta & $\begin{array}{l}\text { Mulberry syrup, carbonated water, black mulberry, parsley, sugared cotton, salt, } \\
\text { pomegranate syrup. }\end{array}$ \\
\hline Haemorrhoid & $\begin{array}{l}\text { Black sesame, aniseed, hibiscus, olive oil, boiled cabbage, rose hip, pumpkin seed, } \\
\text { apricot compote, sitting on hot bracket, sparrow meat, cirrus, harmal seed, gentian. }\end{array}$ \\
\hline Intestinal worms & $\begin{array}{l}\text { Eating apricot on an empty stomach, garlic, pumpkin seed, gasoline, carrot, strawberry, } \\
\text { fig, vinegar - yogurt, cassia. }\end{array}$ \\
\hline Hepatitis & $\begin{array}{l}\text { A small cut on forehead with knife, juniper syrup, artichoke, compote, drinking pee, } \\
\text { bandaging onion, wearing yellow cloths, grape juice, apricot, lemon. }\end{array}$ \\
\hline Anaemia & $\begin{array}{l}\text { Royal jelly, molasses, black grapes, spleen, kidney, apple, tomato, fig, locust, liver, red } \\
\text { lentil, sesame oil, walnut, apricot. }\end{array}$ \\
\hline $\begin{array}{l}\text { Subconjunctival } \\
\text { hemorrhage }\end{array}$ & $\begin{array}{l}\text { Putting cotton wetted with tea pot onto eyes, putting raw potato onto eyes, dropping } \\
\text { lemon squash, dropping milk, bandaging the eye with egg - white, dropping breast milk } \\
\text { taken from puerperant woman. }\end{array}$ \\
\hline Burn due to hot water & $\begin{array}{l}\text { Barley meal, olive oil, wax, applying ice, apple peeling, paste, fish oil, melted wax, olive } \\
\text { oil, cream of lime, onion, balsam pear, oil from boiled egg, potato extract, applying } \\
\text { tomato paste, cold water, yogurt, flesh, toothpaste, applying egg - white. }\end{array}$ \\
\hline Bleeding & $\begin{array}{l}\text { Applying ice, adding tobacco ash/salt onto the wound, applying olive oil, boiling } \\
\text { santolina, cinnamon, grape juice, vinegar. }\end{array}$ \\
\hline
\end{tabular}

\section{References}

1. Araz A, Harlak H, Meşe G. (2007). Health Behaviors and Alternative Medicine Use, TAF Preventive Medicine Bulletin, 6(2): 112-122

2. Barnes PM, Griner EP, Mc Fann K, Nahin RL. (2004). Complementary and Alternative Medicine Use Among Adults: United States, 2002. Seminars in Integrative Medicine, 2(2): 54-71

3. Cohen RC, Ek K, Pan XC. (2002). Complementary and Alternative Medicine (CAM) Use by Older Adults A Comparison of Self-Report and Physician Chart Documentation, Journal of Gerontology: Medical Sciences, 57(4):223-227

4. Çetin O. (2007). The Use of Complementary and Alternative Medicine in Eskisehir, Sosyo-Ekonomi, JulyDecember, 2:89-106

5. Diraçoğlu R. (2007). Complementary-Alternative Medicine in Rheumatoid Arthritis, Rheumatism, 22:24-30

6. Durmaz B. (2011). Use of Complementary Medicines for Osteoarthritis, Turkish Journal of Geriatrics Supplement, 14(1):83-88

7. Foster DF, Phillips RS, Hamel MB, Eisenberg DM. (2000). Alternative Medicine Use in Older Americans, Journal of the American Geriatrics Society, 48(12):1560-5.

8. Hall HG, Griffiths DL, McKenna LG. (2011). The Use of Complementary and Alternative Medicine by Pregnant Women: A literature Review, Midwifery, 27(6):817-24

9. Hanssen B, Grimsgaard S, Launso L, Fonnebo V, Falkenberg T, Rasmussen N. (2005). Use of Complemantary and Alternative Medicine in Scandinavian Countries, Scandinavian Journal of Primary Health Care, 23:57-62

10. Herrera-Arellano A, Jaime-Delgado M, Herrera-Alvarez S, Oaxaca-Navarro J, Salazar-Martínez E. (2009). The Alternative Medicine Used as Complementary in Patients Positive for HIV, Revistamédica del InstitutoMexicano del Seguro Social, 47(6):651-8 http://www.duyurucu.com/k43114-almanya-da-alternatif-tip.html (Accessed:11.10.2011)

11. Huillet A, Erdie-Lalena C, Norvell D, Davis BE. (2011). Complementary and Alternative Medicine Used by Children in Military Pediatric Clinics. Journal of Alternative and Complementary Medicine, 17(6):531-7 
12. Khalaf AJ, Whitford DL. (2010). The Use of Complementary and Alternative Medicine by Patients with Diabetes Mellitus in Bahrain: a Cross-sectional Study. BMC Complementary and Alternative Medicine, 14(10):35

13. Lim MK, Sadarangani P, Chan HL, Heng JY. (2005). Complementary and Alternative Medicine Use in Multiracial Singapore, Complementary Therapies in Medicine, 13(1):16-24

14. MacLennan AH, Wilson DH, Taylor AW. (1996). Prevalence and Cost of Alternative Medicine in Australia, The Lancet, 347(9001):569-573

15. Muslu GK, Öztürk C. (2008). Complementary and Alternative Treatments and Their Practice in Children, Çocuk Sa ̆̆lı̆̆ ve Hastalıkları Dergisi, 51:62-67

16. Neto JF, Faria AA, Figueiredo MF. (2009). Complementary and Alternative Medicine: Use in Montes Claros, Minas Gerais. Revista da Associação Médica Brasileira, 55(3):296-301

17. Onyiapat JL, Okoronkwo IL, Ogbonnaya NP. (2011). Complementary and Alternative Medicine Use Among Adults in Enugu, Nigeria, BMC Complementary and Alternative Medicine, 4(11):19

18. Özdemir A. (2009). Applications of Complementary Medicine in Chronic Kidney Disease, Postgraduate Thesis (Baskent University, Ankara, Turkey)

19. Richmond JA, Bailey DE, Patel K, Jezsik JA, Muir A, Lin JR, Chow SC, Uzarski D, Mc Hutchison JG. (2010). The Use of Complementary and Alternative Medicine by Patients with Chronic Hepatitis C, Complementary Therapies in Clinical Practice, 16(3):124-31.

20. See A, Teo B, Kwan R, Lim R, Lee J, Tang MB, Verkooijen HM. (2011). Use of Complementary and Alternative Medicine Among Dermatology Outpatients in Singapore, The Australasian Journal of Dermatology, 52(1):7-13

21. Tan M, Uzun O, Akçay F. (2004). Trends in Complementary and Alternative Medicine in Eastern Turkey, The Journal of Alternative and Complementary Medicine, 10(5):861-865

22. Tokem Y. (2006). The Use of Complementary and Alternative Treatment in Patients with Asthma, Tuberculosis ve Thorax, 54(2): 189-196 